\title{
ANTIMICROBIAL ACTIVITY \& PHYTOCHEMICAL ANALYSIS OF LEAF EXTRACT OF BRIDELIA RETUSA
}

\author{
Gopal S. Gond \\ Guru Nanak College Of Science,Ballarpur \\ Corresponding author Email : gond.sg@gmail.com
}

\begin{abstract}
:
The aim of the present work was to investigate the in vitro antimicrobial and preliminary phytochemical analysis of leaf extract of bridelia retusa. In preliminary phytochemical analysis we observed carbohydrate, steroids, alkaloids, tannins and phenolic compounds. Antimicrobial activity was evaluated for eight bacteria such as Proteus vulgaris, Bacillus subtilis, Shigella dysenteriae, Vibrio cholerae, Klebsiella pneumoniae, Staphylococcus aureus, Pseudomonas aeruginosa, Escherichia coli and one fungus Aspergelus niger by using well diffusion method. Acetone extract showed a maximum zone of inhibition in well diffusion method Shigella dysenteriae, B.subtilis and S.aureus showed maximum inhibitory activity.
\end{abstract}

Keywords:

Antimicrobial activity,phytochemicals,folk medicine, herbal extracts.

\section{Introduction:}

Bridelia retusa spreng is one of the important medicinal plants used by the tribes in the treatment of urinary problems. The plant is pungent, bitter, heating, and useful in 'Vata', lumbago, hemiplegia (Kirtikar \& Basu). The root $\&$ bark of this plant are valuable astringents. Hindu practitioners in Western India use the bark for the removal of urinary concretion (Ayurveda). The bark is used as a liniment with gingelly oil in rheumatism (Caius, 1939). In the local herbal medicinal practice water extract of bark of B. retusa is given orally in urinary problems and applied to the wounds. The genus Bridelia includes 60 species, spread over the tropics and subtropics of the old world. Out of these 60, some are used in medicines. Bridelia Montana Willd and Bridelia retusa Spreng are used in indigenous medicines (Caius, 1939). Bridelia retusa is used in diabetis in the indigenous herbal system of India (Manjunath,1990). In the tribal herbal medicine B.retusa is used against sterility (Rai.1985,93). Bark of 
Bridelia retusa is used as anthelmintic in the tribal medicinal system of Tamang tribe of Kabhrepalanchok district, Nepal (Manandhar,1991). Although genus Bridelia has been used widely in folk medicine, it has so far received little phytochemical attention from researchers (Addae-Mensah and Aehenbach, 1985). Recent studies on the phytochemical analysis of B. ferruginea collected from Cameroon in West Africa indicated the presence of terpenoid and flavonoid compounds. The studies on antimicrobial activity of hot water extracts of S. ferruginea from West Nigeria, showed the presence of antibiotic activity against S.aureus and Sarcina lutea; from Minna (Northern Nigeria) antibiotic activity of S. ferruginea showed zone of inhibition against all the tested microorganisms (Irobi et al, 1994). In view of the wide popular use of the of Bridelia retusa, antimicrobial activity was evaluated against 8 bacterial species and one fungus.

\section{Material and Method:}

Collection of Material: Plant material (leaves) was collected from the place called Bhamragarh of Gadchiroli district, Maharashtra. The material was air dried, chopped into pieces and pulverized in grinder and stored in closed plastic containers. Preparation of extracts: Four extracts were prepared from previously dried and powdered plant material by Soxhlet extraction method using ether, chloroform, acetone and methanol solvents. About $300 \mathrm{~g}$ of powdered leaf was extracted until drug exhaustion. The various extracts obtained were evaporated to yield semisolid material which was completely dried in desiccators in vacuum to yield $0.8 \mathrm{~g}$ ether, $1.8 \mathrm{~g}$ chloroform, $60.2 \mathrm{~g}$ acetone and $80.5 \mathrm{~g}$ methanol extracts. The extracts were stored in closed plastic containers at $4^{\circ} \mathrm{C}$ temperature. Test organisms: The test microorganisms used in this study included Proteus vulgaris, Bacillus subtilis, Shigella dysenteriae, Vibrio cholerae, Klebsiella pneumoniae, Salmonella typhi, Staphylococcus aureus, Pseudomonas aeruginosa, Escherichia coli. Aspergillus niger was maintained on potato dextrose agar at $\mathrm{pH} 5.5$ to 6 . Antimicrobial Testing: 
Antimicrobial activity of leaf extract of B. retusa was determined by agar well diffusion method. The four extract obtained by successive extraction of leaves by Soxhlet method were used for antimicrobial testing. The results are shown in the table no.1.Stock solutions of the four crude extracts were prepared by suspending 200mg of extract in DMSO+ Tris mixture (3:7). Further dilutions were made with sterile distilled water. Antimicrobial activity was determined by agar well diffusion method (Perez et al, 1990). Different concentration of extracts 20, 60 and $100 \mathrm{mg} / \mathrm{ml}$ were used to determine the antimicrobial activity. Activity was measured in terms of zone of inhibition in $\mathrm{mm}$ around the well. The results obtained are shown in table no.1. Preliminary Phytochemical Screening: The wide spectrum antimicrobial activity of leaf extracts of Bridelia retusa as shown in the table no. 1 indicates the presence of biologically active compounds in the leaf extract. Therefore, preliminary chemical analysis of the leaf extract of Bridelia retusa was carried out. Different standard tests (Fazly Bazzaz B.S.1997) were performed to find out the active components. The four extracts obtained previously were screened for the detection of antimicrobial compounds. The results obtained are summarized in the Table no.2.

\section{Result and Discussion:}

Table No.1 shows the antimicrobial activity of leaf extracts of B.retusa. Ether extract showed activity against the Gram +ve organisms \& one Gram -ve organisms whereas chloroform extract did not show activity against any test organism. The acetone and methanol extracts were found to be inhibitory to all the test bacteria. The acetone extract produces greater zone of inhibition compared to methanol extract. None of the extract inhibited the growth of Aspergilus niger. Table No. 2 shows the results of preliminary phytochemical analysis of leaf extracts of Bridelia retusa. From the table it is observed that ether and chloroform extract contains steroids. The steroidal concentration of ether extract was found to be greater than chloroform extract. The high concentration of steroids may be responsible for the inhibitory effects against 
S.aureus, B.subtilis and Shigella dysenteriae. The concentration of steroids in the chloroform may not be sufficient for inhibition against the test organisms. The wide spectrum antimicrobial activity of acetone and methanol extract may be due to the presence of alkaloid and tannins. All these compounds are desirable in the extract for the antibacterial activity. Conclusion: It is concluded that the wide spectrum antimicrobial activity of the extract is due the presence of bioactive compounds which confirms that their application in traditional medicine as a treatment of infectious diseases is appropriate and lend some support to traditional claims about the utility of this plant in treatment of some diseases.

\section{Conclusion:}

It is concluded that the wide spectrum antimicrobial activity of the extract is due the presence of bioactive compounds which confirms that their application in traditional medicine as a treatment of infectious diseases is appropriate and lend some support to traditional claims about the utility of this plant in treatment of some diseases.

\section{Acknowledgement:}

The author is very thankful to the Principal for giving permission to carry out the work in the Biochemistry laboratory of the college.

\section{Reference:}

Addae-Mensah, I. and Achenbach, H. (1985) Terpenoids and flavonoids of Bridelia ferruginea. Phytochemistry 24(8), 1817-19.

Caius (1939), Medicinal and Poisonous plants of India. Daramola S.O (1994) Antimicrobial activity of bark extracts of Bridelia ferruginea. $\mathrm{J}$ of Ethnophamacology 43; 185-190. 
Fazly Bazzaz B.S. , Haririzadesh G., Imami S.A. \& Rashed M.HX 1997; Survey of Iranian plants for alkaloids, flavonoids, saponins and tannins. International Journal of pharmacognosy, vol 35, No.1, pp 17 -30.

Irobi,O.N.; M.Moo-Young, W.A. Anderson, S.O. Daramola (1994). J. of Ethnopharmacology 43 185-190.

Kirtikar K.R., Basu B.D.(1980)", Indian Medicinal plants ", Sudhindra Nath Basu, Allahabad, , p 515.

Kirtikar, K.R., Basu, B.D., (1991) Indian Medicinal Plants, Vols. I-IV.

Bishen Singh Mahendra pal Sing, Dehra Dun, India.

Maheshwari, J.K., K.K. Singh IrobiO.N., Moo-Young, Anderson W.A., Daramola S.O (1994) Antimicrobial activity of bark extracts of Bridelia ferruginea. J. of Ethnophamacology 43; 185-190.

Maheshwari, J.K., K.K. Singh IrobiO.N., Moo-Young, Anderson W.A., Daramola S.O (1994) Antimicrobial activity of bark extracts of Bridelia ferruginea. J. of Ethnophamacology 43; 185-190.

Manjunath, T.N. (1990). "Present Status and future strategies for research need and policies in Central India", in 'Proceedings of Medicinal and Aromatic Plants,' I, pp $141-46$.

Manandhar, N.P.(1991) 'Medicinal Plant-lore of Tamang Tribe of Kabhrepalanchok district .Nepal',Economic-botany,45(1)pp 58-71.

M. C. Cordeiro, B. B. Kaliwal. Protective role of bark extract of Bridelia retusa Spreng on CCl4 induced histological toxicity in mice. Journal of Pharmacognosy and Phytochemistry 2013; 2 (4): 145-151

Perez , C.,Pauli, M. and Bazerque, P. (1990) An antibiotic assay by the agarwell diffusion method. Acta Biologiae et Medicine Experimentalis 15,11315. 
Rai, M.K. (1985) Plants used as medicine by tribals of Chhindwara district (Madhya Pradesh) J. Econ. Taxon. Bot. 7(2) 385-387.

Rai, M.K. (1993). A note on ethnomedical studies of Chindwara, plants used in shake and scorpion bite, Aryavaidyvan. 7(1): 45 - 50.

Ranjan, R. and *Deokule, S. S. Pharmacognostic Evaluation Of Bridelia retusa spreng. International Journal of Current Research Vol. 5, Issue, 06, pp.1599-1602, June, 2013

Table No 1: Antimicrobial activity of leaf extract of $B$. retusa

\begin{tabular}{|c|c|c|c|c|c|c|c|c|c|c|c|c|c|}
\hline \multirow{3}{*}{ TEST ORGANISM } & \multirow{3}{*}{$\begin{array}{l}\text { Negat. } \\
\text { Contrl. } \\
\text { DMSO }\end{array}$} & \multicolumn{12}{|c|}{ Zone of inhibition\# } \\
\hline & & \multicolumn{3}{|c|}{$\begin{array}{l}\text { Ether } \\
\text { extract } *\end{array}$} & \multicolumn{3}{|c|}{$\begin{array}{l}\text { Chloroform } \\
\text { extract }\end{array}$} & \multicolumn{3}{|c|}{$\begin{array}{l}\text { Acetone } \\
\text { extract }\end{array}$} & \multicolumn{3}{|c|}{$\begin{array}{l}\text { Methanol } \\
\text { Extract }\end{array}$} \\
\hline & & $\begin{array}{r}20 \\
\mathrm{mg}\end{array}$ & $\begin{array}{r}60 \\
\mathrm{mg}\end{array}$ & $\begin{array}{r}100 \\
\mathrm{mg}\end{array}$ & $\begin{array}{l}20 \\
\mathrm{mg}\end{array}$ & $\begin{array}{r}60 \\
\mathrm{mg}\end{array}$ & $\begin{array}{l}100 \\
\mathrm{mg}\end{array}$ & $\begin{array}{l}20 \\
\mathrm{mg}\end{array}$ & $\begin{array}{l}60 \\
\mathrm{mg}\end{array}$ & $\begin{array}{l}100 \\
\mathrm{mg}\end{array}$ & $\begin{array}{r}20 \\
\mathrm{mg}\end{array}$ & $\begin{array}{r}60 \\
\mathrm{mg}\end{array}$ & $\begin{array}{l}100 \\
\mathrm{mg}\end{array}$ \\
\hline \multicolumn{14}{|l|}{ Gram +ve Bacteria } \\
\hline S.aureus & 0 & 9 & 11 & 12 & 0 & 0 & 0 & 12 & 14 & 16 & 9 & 10 & 12 \\
\hline B.subtilis & 0 & 12 & 13 & 14 & 0 & 0 & 0 & 11 & 13 & 15 & 8 & 9 & 10 \\
\hline \multicolumn{14}{|l|}{ Gram - ve Bacteria } \\
\hline E.coli & 0 & 0 & 0 & 0 & 0 & 0 & 0 & 0 & 9 & 11 & 0 & 8 & 11 \\
\hline K.pneumoniae & 0 & & 0 & 0 & 0 & 0 & 0 & 0 & 10 & 12 & 9 & 11 & 12 \\
\hline P.aeruginosa & 0 & 0 & 0 & 0 & 0 & 0 & 0 & 0 & 9 & 10 & 0 & 0 & 9 \\
\hline P.vulgaris & 0 & 0 & 0 & 0 & 0 & 0 & 0 & 9 & 11 & 14 & 9 & 10 & 12 \\
\hline S.dysenteriae & 0 & 12 & 14 & 17 & 0 & 0 & 0 & 14 & 16 & 20 & 16 & 18 & 20 \\
\hline V.cholerae & 0 & 0 & 0 & 0 & 0 & 0 & 0 & 10 & 12 & 13 & 9 & 11 & 12 \\
\hline \multicolumn{14}{|l|}{ Fungus } \\
\hline A.niger & 0 & 0 & 0 & 0 & 0 & 0 & 0 & 0 & 0 & 0 & 0 & 0 & 0 \\
\hline
\end{tabular}

\# - Including diameter

of zone
Extract * - Conc. of extract $\mathrm{mg} / \mathrm{ml}$ of zone 0 - No inhibition 
Table no 2. Results of phytochemical analysis of leaf of B.retusa.

\begin{tabular}{|c|c|c|c|c|}
\hline \multirow{2}{*}{ Tests } & \multicolumn{4}{|c|}{ Extracts } \\
\hline & Ether & Chloroform & Acetone & Methanol \\
\hline \multicolumn{5}{|l|}{ Tests for sterols : } \\
\hline Salkowski's test & +++ & ++ & - & - \\
\hline Liberman test & +++ & ++ & - & - \\
\hline Liberman Burchard test & +++ & + & - & - \\
\hline Tests for Alkaloids: Dragendorff's test & - & - & ++ & +++ \\
\hline Mayer's reagent & - & - & ++ & +++ \\
\hline Wagner's reagent & - & - & ++ & ++ \\
\hline Hager's reagent & - & - & ++ & ++ \\
\hline Tannic acid reagent & - & - & ++ & +++ \\
\hline Scheibler's reagent & - & - & ++ & +++ \\
\hline Test for Saponins: Foam test & - & - & - & - \\
\hline Tests for flavoroids: & - & - & - & - \\
\hline \multicolumn{5}{|l|}{ Test for cardiac glycosides: } \\
\hline Keller killiani test & - & - & - & - \\
\hline Legal's test & - & - & - & - \\
\hline \multicolumn{5}{|l|}{ Tests for cynogenetic glycosides } \\
\hline Grignard's test & - & - & - & - \\
\hline \multicolumn{5}{|l|}{ Test for anthroquinones: } \\
\hline Bortranger's test & - & - & - & - \\
\hline Test for Tannins: $\mathrm{FeCl}_{3}$ test & - & - & + & + \\
\hline Lead acetate test & - & - & + & + \\
\hline Potassium diachromate test & - & - & + & ++ \\
\hline Gelatin solution test & - & - & + & +++ \\
\hline Bromine water test & - & - & + & + \\
\hline Tests for phenols : $\mathrm{FeCl}_{3}$ test & - & - & + & - \\
\hline $\mathrm{HNO}_{3}$ test & - & - & + & - \\
\hline Phthalic acid test & - & - & + & - \\
\hline Test for proteins : Biuret test & - & - & - & - \\
\hline Xanthoproteic test & - & - & - & - \\
\hline Millon's test & - & - & - & - \\
\hline Tests for amino acids : Ninhydrin test & - & - & - & - \\
\hline Test for Carbohydrates: Molisch's test & - & - & ++ & +++ \\
\hline Barfoed's test & - & - & - & - \\
\hline Fehlorg's test & - & - & - & - \\
\hline
\end{tabular}

